\title{
"AUFHEBUNG" DE LOS DIQUES ANIMICOS EN EL AMOR Y EL DUELO
}

\author{
“Aufhebung” das Barragens Psiquicos em Amor e Luto \\ “Aufhebung” Dams of Psychic in Love and Mourning \\ "Aufhebung" des Barrages Psychiques dans L'amour et le \\ Deuil
}

\section{Resumen}

Freud, respecto a la sexualidad y sus pretensiones de placer parcial inscribe el concepto hegeliano de "Aufhebung". Establece una perspectiva dialéctica en el despliegue de apetencia pulsional de placer. No hay placer sin ley, sin límite. Propone la vergüenza, el asco y la moral, como diques anímicos en la búsqueda de placer pulsional. El goce, plus-de-placer, se desprende de sobrepujar esta función límite del dique anímico. Es lo que las tecnologías cibernéticas ofrecen al amor, cancelando los limites entre público y privado. El amor en línea auspicia la irrupción de la osadía superando los diques anímicos. La tecnología deifica la imagen en un encuentro desafiante que hace a un lado los escrúpulos, en nombre de un amor dispuesto a todo ante un desconocido. Se cultivan relaciones imaginarias donde el cuerpo aparece como súbdito de la voluntad imperiosa de un otro enaltecido. Estos cuerpos impúdicos y tecnificados, en el escenario del amor también se pueden mostrar en sus heridas y mutilaciones. Sin pudor se entrega el cuerpo a la mirada sorprendida del otro. También en la pérdida de ese amor, o la del ser amado se ven surcadas por la impudicia. Dos mujeres realizan sobre sus cuerpos los intentos de subjetivación de sus pérdidas. El dolor, otro dique, otro límite en la meta pulsional del placer, es superado al abrir el cuerpo a la mirada del otro. El amor en línea derroca los límites exhibiendo lo privado y el duelo oscila entre hacer del cuerpo un ejercicio de masacre y privatizar el ritual. Los diques pueden inscribirse como resistencia al duelo, y pueden anteponerse a toda experiencia de duelo. Esas funciones del límite se dirigen a la movilización de placer y el goce. También pueden sofocar, bloquear, el trámite subjetivo del duelo, en tanto reconocimiento y simbolización de la falta.

Palabras clave: Aufhebung; diques anímicos; amor; duelo; exposición del cuerpo; dolor.

\section{Resumo}

Freud, sobre a sexualidade e suas pretensões de prazer parcial, inscreve o conceito hegeliano de "Aufhebung". Estabelece uma perspectiva dialética no desdobramento de apetência pulsional de prazer. Não há prazer sem lei, sem limite. Propõe a vergonha, o asco e a moral como diques anímicos na busca de prazer pulsional. O gozo, plus-de prazer, desprendese de sobrepujar esta função limite do dique anímico. É o que as tecnologias cibernéticas oferecem ao amor, cancelando os limites entre público e privado. $\mathrm{O}$ amor em linha auspicia a irrupção da ousadia, superando os diques anímicos. A tecnologia diviniza a imagem num encontro desafiante que deixa a um lado os escrúpulos, em nome de um amor disposto a tudo ante um desconhecido. Cultivam-se relações imaginarias nas quais o corpo aparece como súdito da vontade imperiosa de um outro enaltecido. Estes corpos impudicos e tecnificados no cenário do amor também podem mostrar-se nas suas feridas e mutilações. Sem pudor, entrega-se o corpo à mirada surpreendida do outro. Também na perda desse amor, ou a do

Mario Orozco Guzmán ${ }^{(1)}$ Hada Soria Escalante ${ }^{(2)}$

1) Profesor Investigador de la Facultad de Psicología. Universidad Michoacana de San Nicolás de Hidalgo. Miembro del SNI. Miembro de Espacio Analítico Mexicano.

2) Doctorado Interinstitucional en Psicología. Universidad Michoacana de San Nicolás de Hidalgo. Miembro de Espacio Analítico Mexicano. 
ser amado, é sulcado pela impudicícia. Duas mulheres realizam sobre seus corpos as intenções de subjetivação de suas perdas. A dor, outro dique, outro limite na meta pulsional do prazer, é superada ao abrir o corpo à mirada do outro. O amor em linha derroca os limites, exibindo o privado, e o duelo oscila entre fazer do corpo um exercício de massacre e privatizar o ritual. Os diques podem inscrever-se como resistência ao duelo e podem se antepor a toda experiência de duelo. Essas funções do limite dirigem-se à mobilização do prazer e do gozo. Também podem sufocar e bloquear o trâmite subjetivo do duelo, em tanto reconhecimento e simbolização da falta.

Palavras-chave: Aufhebung; diques anímicos; amor; duelo; exposição do corpo; dor.

\section{Abstract}

Freud on sexuality and its claims of partial pleasure enters the Hegelian concept of "Aufhebung”. It establishes a dialectical perspective on the unfolding of instinctual craving for pleasure. There is no pleasure without law, without limit. It proposes shame, disgust and morality as animistic beliefs in search of instinctual pleasure. The enjoyment loosens to overcome this limit function of the animistic belief. It is what the cybernetic technologies offer to love, canceling the boundaries between public and private. The online love promises the eruption of daring, overcoming animistic beliefs. The technology deifies the image in a challenging encounter that leaves aside the scruples on behalf of a willing love before an unknown person. Imaginary relationships in which the body appears as subject of imperious will of another one exalted is cultivated. These lewd and technified bodies in the scenery of love can also show up in their wounds and mutilations. Shamelessly indulges the body to surprised glance of the other. Also in the loss of this love, or of being loved, is furrowed by unchastity. Two women carry on their bodies the subjectivity intentions of their losses. Pain, another belief, another limit on the instinctual goal of pleasure, is overcome when opening the body to the other glance. The online love debacle limits, displaying the private, and the duel oscillates between making the body an exercise of massacre and privatizing ritual. Beliefs can sign up as resistance to the duel and can be raised against the whole dueling experience. These limit functions address to the mobilization of pleasure and enjoyment. They can also smother and block the subjective processing of the duel, both in recognition and symbolization of lack.

Keywords: Aufhebung; animistic beliefs; love; duel; body exposure; ache.

\section{Résumé}

Freud, à propos de la sexualité et de ses prétentions de plaisir parciel, utilise le concept de Hegel "Aufhebung ». Il établit une perspective dialectique dans le dédoublemet de l'appétence pulsionnelle de plaisir. Il n'y a pas de plaisir sans loi, sans limite. Il propose la honte, la répugnance et la morale comme des digues animistes dans la poursuite de plaisir pulsionnel. La jouissance, plus de plaisir, se détache de dépasser cette fonction limite du digue animiste. C'est ça que les technologies cybernétiques offrent à l'amour, en annulant les limites entre ce qui est public et ce qui est privé. l'amour en ligne prédit l'irruption de l'audace, en surpassant les digues animistes. La technologie divinise l'image dans une rencontre défiante, et les scrupules sont déconsidérés à couse d'un amour bien déterminé en face de l'inconnu. On cultive des relations imaginaires dans lesquelles le corps apparaît sujet au souhait de l'autre exalté. Ces corps sans pudeur et technifiés dans la scène de l'amour peuvent se montrer avec ses blessures et mutilations. Sans pudeur on offre le corps au regard surpris de l'autre. Au momment de la perte de cet amour, ou de la personne aimée, on est frappé par l'impudicité. Deux femmes réalisent sur leur corps les instentions de subjectivité de leurs pertes. La douleur, un autre digue, une autre limitation de la pulsion du plaisir, est supérée quand on offre le corps au regard de l'autre. L'amour en ligne détruit les limites et expose le privé, ainsi le duel varie entre l'action d'utiliser le corps comme un exercice de massacre et celle de privatiser le rituel. Les digues peuvent s'instaurer comme la résistence au duel ou s'y opposer. Cettes fonctions du limite se conduit à la mobilisation du plaisir et de la juissance. Elles peuvent aussi bloquer la variété subjective du duel et le transformer en reconnaissence et symbolisation de l'absence.

Mots-clés: Aufhebung; digues animiques; amour;duel; exposition du corps; douleur.

\section{Poderes Suprimidos, Poderes Conservados}

El concepto de Aufhebung es esencial para la dialéctica elaborada por el pensamiento hegeliano. Sustenta la antítesis fundamental en el movimiento de la conciencia: "la superación presenta su verdadera doble significación, que hemos visto en lo negativo: es al mismo tiempo un negar y un mantener" (Hegel, 1982, p. 72). Es Jean Hyppolite quien detecta la presencia de esta Aufhebung en su doble significación en Freud en el texto sobre La Negación:

Es la palabra dialéctica de Hegel, que quiere decir a la vez negar, suprimir y conservar, y en el fondo levantar. En la realidad, puede ser la Aufhebung de una piedra, o también la cesación de mi suscripción a un periódico. (Hyppolite, 1989, citado por Lacan, p. 860)

El trabajo que presentamos es un intento de situar esta Aufhebung respecto a los llamados diques anímicos planteados por Freud en relación con la búsqueda de placer libidinal alentada por las pulsiones parciales; en particular con dos apuestas contemporáneas de ejercicio de 
individualismo del goce en algunos adolescentes: el amor en línea y las escarificaciones. El trabajo también da cuenta de cómo un poder resistencial, actuando a modo de barrera afectiva, puede anteponerse al proceso de duelo.

La Aufhebung en Freud aparece cuando se intenta esclarecer cómo los poderes resistenciales de dichos diques serían superados por la tendencia placentera de la pulsión de ver: "Die Macht, welche der Schaulust entgegensteht und eventuell durch sich aufgehoben ist die Scham (wie vorhin der Ekel)" (Freud, 1905/1999, p. 56), el poder, al cual el placer de ver se opone y eventualmente suprime, es la vergüenza (como hace un momento el asco). Encontramos precisamente ahí esta bifurcación de significaciones. Es decir, un poder negado, suprimido, pero mantenido. Para el caso del dolor podemos señalar que es hasta que Freud se introduce con las cuestiones del sadismo y el masoquismo que incorpora a este factor entre los diques anímicos: "El dolor así superado se alinea junto con el asco y la vergüenza, que se oponían a la libido en calidad de resistencias" (Freud, 1905/2006b, p. 144). Poderes que se doblegan ante la embestida del placer de ver y de hacer doler al otro (a sí mismo) o hacerse doler por el otro (por sí mismo) pero que se conservan. El excedente de placer lo suministra el hecho de que los movimientos de despliegue libidinal no se emprenden sin oposición, sin resistencia. El poder resistencial se mantiene a pesar de ser negado por el placer visual y el placer violento sobre el cuerpo del otro o sobre el cuerpo propio. Lo cual le da plus-de-valor al disfrute. Aunque no por ello quede cancelado, suprimido dicho poder.

\section{La Impudicia en el Escenario Virtual del Amor}

La apuesta perversa se solaza en franquear dicho poder resistencial de los diques anímicos en condición de límites, se complace en subvertirlos y confundirlos. Ha encontrado en los actuales medios cibernéticos un soporte suculento para este franqueamiento y subversión. Advertíamos cómo se posicionaba el factor límite en tanto poder que pretendía circunscribir, cercar, con la organización defensiva del yo, el poder libidinal y cruel del placer; el cual sin embargo se afirmaba y confirmaba hasta el exceso en la transgresión: "La fuerza de la pulsión sexual gusta de afirmarse venciendo este asco" (Freud, 1905/2006a, p. 138). Pero también venciendo la oposición de la vergüenza y la moral. Es un querer, un gusto (Lieben), muy destacable éste que se dedica a la Überwindung (Freud, 1905/1999, p. 51), superación, de las fuerzas contrarias, de las fuerzas de lo contrario, de las fuerzas del otro que opone intensa resistencia a la pretensión pulsional de carácter parcial. Los medios cibernéticos, en esta exaltación imaginaria de lo individual, parecen plegarse a la afirmación del gusto pulsional cuando suscriben una erosión de los límites entre lo público y lo privado. Sostienen por vía tecnológica un ejercicio de impudicia, de superación-conservación del poder resistencial, infundiendo un plus-de-placer, una experiencia de goce. A tal punto que Galimberti (2011) habla de una homologación de lo íntimo que se sustenta en cómo los medios tanto comunicacionales como los de la industria del internet:

[...] hacen irrupción de manera indiscreta en la vida del individuo apoderándose de su parte más discreta para obtener rebanadas de vidas privadas, no sólo por medio de tests, de cuestionarios, muestreos, estadísticas, sondeos de opinión, encuestas de mercado, pero también y sobre todo por unas confesiones íntimas, unas emociones en directo, unas historias de amor reveladas en público. Es el mismo individuo mismo que entonces confía su propia intimidad, su parte más discreta, haciendo públicos sus sentimientos, sus emociones, sus sensaciones, entregándose a unos estallidos de impudor como otras tantas expresiones de su $<$ sinceridad $>$. (p. 132)

Es la sociedad de la expresividad impúdica. Donde se apuesta por no tener vergüenza de nada ni ante nadie. Las pantallas introducen un marco especular, imaginario, ideal, recortándose de la realidad, donde se levantan las barreras del pudor, el asco y el dolor. Brindan el escenario magnificente de la osadía, de la subversión, de la permisibilidad y la impunidad. Escenario festivo de la violencia: "Aquí está todo permitido. No se castiga nada" (Coetzee, 2003, p. 184). Ese levantamiento de las barreras es correlativo al levantamiento de la contrainvestidura de la represión. El cual eventualmente para Freud (1905/2006b) daba cuenta de las condiciones económicas del chiste, donde la "ganancia de placer corresponda al gasto psíquico ahorrado" (p. 114). El gasto de investidura que se ahorra mediante el chiste es el que exige el sostenimiento constante, permanente, de la represión.

El amor mismo encuentra en el escenario virtual condiciones adecuadas para el despliegue de lo impúdico. Se ahorra el gasto económico de la represión mediante el encuentro en línea con otro con el cual puede permitirse todo, con el cual puede permitirse al sujeto todo lo que es difícil que se permita en un intercambio sin mediación ni resguardo del monitor especular. El contacto digital se impone y prescinde del contacto piel a piel. O lo escamotea de esta manera. El amor en línea está prendido de la ilusión de sustraerse al estado de vulnerabilidad que implica siempre su régimen pasional comprometido en la inmediatez corporal. El amor virtual atraviesa de esta manera los umbrales de la vergüenza, el asco, el dolor, la moral, pero los involucra en el aliento del goce de su desafío. Es lo que mejor demuestra que el amor en las "condiciones de radicalización del individualismo" (Galimberti, 2011, p.11), sustentado en la portentosa digitalización de la tecnología, 
se constituye como una búsqueda del otro, no tanto en la prestancia diferenciada de la posible trascendencia, sino para la realización de su "propio yo profundo" (p. 11). Es decir, prevalece la vertiente narcisista en la elección de objeto tal como Freud (1914/2006) la plasmara como vía de reencuentro con las imágenes idealizadas del yo a través del otro. Después de todo, como lo afirma Lacan (1965), "el yo se forma de las historias sucesivas de los yo ideales" (p. 140). El otro del encuentro virtual debe posibilitar la extensión, la exploración, narcisista del yo del individualismo exacerbado. De allí la impresión de utilización, de sensación de usura, que impregna muchas de las experiencias amorosas cuando la ceguera pasional impide discernir "si el otro desea trascenderse en mi cuerpo o simplemente usarlo" (p. 77). En el amor virtual predomina esta Erlebnis (vivencia) utilitaria del cuerpo. El cual de todos modos parece prestarse a todas las mediaciones imaginarias que comanda el espectro de un deseo que parece decirse sin tapujos, sin pudor ni vergüenza. En esta época, donde los jóvenes cultivan con enorme riesgo de violencia sus pasiones, se ha desplegado, con gran capacidad de convocatoria y fascinación, el amor en línea:

Dejar su deseo desencadenarse por una persona ausente o inaccesible, para el extranjero misterioso, ofrece no sólo la posibilidad de explorar lo interdicto y lo efímero, sino también de fantasear sobre lo interdicto y sobre lo efímero desde un lugar abrigado, no poniendo en peligro nuestras relaciones reales, que no escuchamos autorizarnos a verdaderamente desestabilizar. (p. 99)

Podríamos aseverar que en el amor en línea el otro, bajo la cobertura de la imagen siempre captada en la vertiente mágica y omnipotente, está presente y resulta sumamente accesible. Pero no su cuerpo en su densidad real. Como en el universo del Hades visitado por Odiseo que, al no aprehender el cuerpo de los muertos, se conforma con sus sombras, escurridizas, inaprehensibles. El escenario virtual no se expone al riesgo del intercambio real de los cuerpos, a su exploración inédita, sorprendente, pero brinda un espacio donde palabras e imágenes se arriesgan en el decir y en el mostrarse. En la línea del abrigo, de su guarnición, el cuerpo llevado a lo virtual es ideal para la plasmación del fantasma y su despliegue lúdico. Se emprende pues una verdadera puesta en escena de juegos de seducción y atrevimiento, de osadía y procacidad, que nos remite a la complicidad libidinosa de la figura materna, planteado por Joël Dor (1996) como factor favorecedor de la perversión como un verdadero llamado corporal "en el terreno de dar a ver, a oír, a tocar o a sentir" (p. 117). Así una chica se permite con su partenaire del intercambio cibernético la osadía de darle a oír y a ver expresiones e imágenes pero bajo una demanda imperiosa. En estas condiciones también el cuerpo es empujado, forzado, a adoptar posturas y acciones bajo la voluntad veleidosa del otro. La ciencia de la tecnología virtual opera como cómplice o coartada de este goce que se despliega en el campo de la mirada no sin comprometer la coerción violenta: "La ciencia es también aparatos, instrumentos, productos, drogas, en una palabra, objetos que estorban y violentan el cuerpo, y cada cuerpo tiene una época correlativa a la época de la ciencia" (Nasio, 2006, p. 74). Es decir, se trata de aprovechar los avances de la ciencia en el campo de la tecnología virtual para propiciar encuentros en los cuales se libere de todo pudor un cuerpo ante el poder acuciante de la demanda del otro. Todo se define en la formalidad de la imagen, en su especularidad obsequiosa, exquisita, para que cualquiera pueda devenir amo del otro; más que amor del otro.

La impudicia supura y satura otros ámbitos. Se trata de hacer que lo interno fluya como algo abyecto y se desparrame en el exterior, superando-conservando los poderes resistenciales del pudor y el asco:

Entonces la abyección se sostiene como lugar de otro, hasta el punto de procurarle un goce, con frecuencia el único para el borderline, que en virtud de ello transforma al abyecto en lugar del Otro. Este habitante de la frontera es un metafísico que impulsa desde lo imposible hasta la escatologia. (Kristeva, 2006, p. 74)

El cine ve concurrir en sus aventuras de ciencia-ficción el espectáculo de cuerpos que no acaban de morir, insepultos y sanguinolentos, zombis, arrebatados por instintos voraces. Cuerpos degradados portando y exhibiendo los flujos de un interior socavado, devastado. El cuerpo mismo es flujo de una abyección al cual parece rendírsele "culto erótico" (Kristeva, 2006, p. 75). Es el erotismo de lo impúdico brotando de un cuerpo donde la diferencia adentro-afuera esta arruinada. Son los cuerpos víctimas de los fracasos de la ciencia que prometía hacer del hombre, como afirmaba Freud (1929-30/2006), "una suerte de dios-prótesis, por así decir, verdaderamente grandioso cuando se coloca todos sus órganos auxiliares" (p. 90). Films como Yo soy Leyenda (Goldsman \& Lawrence, 2007), Serenity (Buchanan \& Whedon, 2005), Guerra Mundial Z (Kleiner \& Forster, 2013), entre otros, plasman a los hombres muy lejos de la grandeza de un dios y más cerca de la degradación animal. La emergencia del mal, de la crueldad instintiva, está adherida a cuerpos que la ciencia pretendió eximir de todo mal ¿será que la ciencia se ha empeñado en pensar el cuerpo reducido o seducido por su indomable condición instintiva y biológica?

\section{La Aufhebung del Dolor}

Pero el cuerpo para el psicoanálisis no se reduce a lo biológico. El cuerpo del psicoanálisis se constituye como 
superficie erogeneizada, como superficie libidinal como superficie agujerada por las pulsiones. Todo lo cual subvierte su organicidad biológica: "La noción de subversión...fue propuesta hace algunos años para explicar la lucha que libra el sujeto para construir un orden psíquico gracias al cual intenta liberarse del orden fisiológico" (Dejours, 1992, p. 9). El cuerpo erótico es la referencia fundamental para suscribir esta subversión que da cuenta del orden subjetivo. El cuerpo, entonces, posee una dimensión imaginaria, dando espacio a las fantasías inconscientes que resultan insoportables al yo del sujeto. Espacio de síntoma histérico hecho de la confluencia paradójica de los fantasmas inconscientes. A lo que alude Freud (1908/2006) cuando el ataque histérico reedita en su convulsiva contractura un atentado sexual y su desesperada resistencia. Pero también espacio donde se recrea y solaza el amor en línea. Es, además, un cuerpo atravesado por las palabras, un cuerpo que relata, da cuenta de acontecimientos. Se construye como superficie narrativa, delatora, constituyendo las articulaciones de una historia de sujeto. Si el síntoma corporal puede dar cuenta de algo desarticulado en la historia de un sujeto, las palabras pueden articular al cuerpo con la historia, subjetivarlo. Las palabras hacen el cuerpo del lenguaje y hacen del cuerpo lenguaje, al punto de que las posturas corporales puede ser "indicio del deseo" (p. 123). Los sufrimientos, el dolor, ofrecen los rasgos que caracterizan a la dimensión real del cuerpo. Dimensión desgarrada del cuerpo, dimensión que conduce al cuerpo abierto, al cuerpo que se abre exponiendo sus heridas. Si el amor en línea sobrepuja todo pudor, supera toda vergüenza, el desafío moderno es sobrepujar el dolor. Ni la vergüenza ni el dolor pueden detener al Yo de del radicalismo individual de la época tecnológica.

En la contemporaneidad, el cuerpo obtiene un estatuto prioritario para los sujetos. ¿Cómo son estos cuerpos de la actualidad? Son, en primer lugar, los cuerpos herederos de una tradición modernista que los sublevaba de su condición biologicista, cuerpos sometidos a la voluntad ilimitada del hombre de la Modernidad, cuerpos sometidos a la fragmentación, al estudio, a alcanzar el nivel sobrevalorado e inalcanzable de cuerpo-máquina. Cuerpos ideales. Con el advenimiento de la Posmodernidad, estos cuerpos fragmentarios y automatizados, llevaron su condición de ideales más allá de lo imaginado por los teóricos de la Modernidad, ya que su carnalidad desgarrada, devino real. Vattimo (1987) destaca que "lo posmoderno no es 'lo contrario' de lo moderno, sino su rebasamiento. Es la modernidad misma que en su autocumplimiento invierte sus modalidades y efectos culturales" (p. 3). Los cuerpos tecnificados de la actualidad son más reales: carne, sangre, vísceras, partes del cuerpo sustituibles por otras, mejoradas. Las demandas y denuncias subjetivas se escriben sobre los cuerpos modificables.

Para Lyotard (1991), la experimentación juega un papel indispensable en la cultura posmoderna. Es una invitación a no dejar de jugar con el lenguaje y las posibilidades de lo humano. Lyotard invoca a nuevas formas de comunicación. También el cuerpo habla en la diversidad semiótica de los comportamientos kinésicos (Picard, 1986) ahora llevados a las pantallas de los sistemas cibernéticos. Posmodernos para Lyotard, hipermodernos para Lipovetsky (2006), los cuerpos de la actualidad son superficies narrativas que se desenvuelven para darle intimidad a lo extraño, al desconocido, en la línea relajada del amor virtual. Esta cultura de lo visual lleva su propio malestar como fardo, pues implica cegueras, implica que no todo resulta visible. En esta época de la acentuación del poderío individualista del yo, Courtine (2006) resalta el enunciado de Primo Levi: "Mi cuerpo no es más mi cuerpo" (p. 11). Experiencia de expropiación corporal como una cuestión cultural, antropológica. No es azaroso que en la época contemporánea, la hipermodernidad, más que en cualquier otra, el cuerpo se presenta como lugar predilecto de la experimentación, de las transformaciones y las exposiciones. Implantes, tatuajes, prótesis, escarificaciones, cirugías estéticas, una reafirmación obstinada de la tenencia corporal. La apropiación corporal, en tanto feudo narcisista, se corrobora en que se podría disponer del cuerpo para hacer de él lo que veleidosamente se quisiera. Acomodarlo sobre todo a una voluntad férrea tanto ética como estética. Sobre el cuerpo mismo recae incluso el desafío a la muerte. Aditamentos tecnomédicos se ponen en juego para que el cuerpo sobreviva; suplencias orgánicas o piezas artificiales, aparatos de control cibernético, que se integran a un cuerpo, sobrepujando vergüenza y dolor:

[...] emergencia de nuevas formas y de nuevos poderes, tanto biológicos como políticos; la salud devenida un derecho y la ansiedad frente al riesgo, la búsqueda del bienestar individual y la extrema violencia de la masa, el contacto de las pieles en la vida íntima y la saturación del espacio público por la frialdad de los simulacros sexuales. (Courtine, 2006, p. 11)

\section{EI Cuerpo Surcado por la Pérdida}

El sujeto de nuestra época hace narrativa de su cuerpo. Dentro de la impudicia propia de la época comandada por la tecnología, el sujeto somete su cuerpo a una violencia que es delatora de otra, de las pérdidas que en su vida lo van marcando. Escarificar, hacer agujeros sobre la piel, es también una forma de representar otros agujeros, los abiertos por las pérdidas. La pérdida subjetiva abre nuevos agujeros, nuevos orificios. La pérdida de los objetos amados también es un agujero, menciona Lacan (1959), en lo real que pertenece a lo indecible, lo irreconocible, sin posibilidad de significación. Objetos que adquieren la 
condición de amados en tanto sustento del deseo del sujeto ahora implican, con su condición de pérdida, un dolor que parece arruinar el deseo. Estas pérdidas se presentan desde lo más concreto, irremisible de muertes reales de seres queridos, hasta lo más abstracto, como aquellas designadas por Freud relativas a los ideales, la patria, entre otras. Ese agujero en lo real que aparece con la muerte de un objeto amado, retorna a manera de irrupción violenta. Siguiendo con la línea de pensamiento de Lacan, advertimos cómo el sujeto en duelo intentará integrar la dimensión simbólica a eso real. A partir de aquí comienza "la puesta en juego total de todo el sistema significante alrededor del mínimo duelo" (Lacan, 1959/2014b, p. 373).

Hacer duelo es entonces significar la pérdida, responde a ese proceso simbólico de introducción del significante donde no lo hay, donde la irrupción violenta de lo real de la muerte pone barrera a la significación y asunción subjetiva. Ese proceso de subjetivación de la pérdida puede darse a través del cuerpo. Por tanto, emerge el duelo como proceso de conversión del agujero emanado de la pérdida en otra cosa que se incorpora. Subjetivación del duelo que se emprende mediante la violencia corporal. Pues los procesos del duelo son diversos, también lo son sus destinos. El cuerpo como primer receptor en lo concreto-real de la pérdida es una de las vías posibles en la ruta hacia la subjetivación el duelo.

Un caso da cuenta de éste intento subjetivante del duelo sobre el cuerpo. Una joven, adolescente, lleva a cabo escarificaciones sobre su cuerpo, principalmente en sus piernas. Se trata de un ejercicio de encarnación del duelo, un duelo perturbado, de un dolor que remite a una pérdida que de otro modo no ha podido ser expresada, tampoco apalabrada. El dolor es sobrepujado en la medida en que cada corte le permite rememorar el dolor de sus acercamientos sexuales con un hombre mayor, un pariente cercano, que ha muerto. Es también el dolor por un deseo sentido como culpable y la reaparición del asco da cuenta de ello. El fenómeno de la ambivalencia descrito por Freud y constituyente de un duelo atípico se hace presente, mezclando su placer con la culpa de haberlo sentido. Después de haber deseado su muerte, no hay un duelo en sus manifestaciones típicas, no hay llanto, no hay sufrimiento por el muerto, no hay ni inhibición, ni pérdida de interés por el mundo. En cambio, lo que hay es asco, repugnancia y un sentido de venganza que ella nombra:

[...] en el velorio fue así como de... está muerto, ¿y? No me importó pero sí me dio asco. Si pienso en él sólo pienso en que ya no está, y ya cuando lo estaban enterrando estaba enojada y le dije que las cosas se regresan y iqué bueno!(Soria, 2011, p. 148)

La reaparición del dique anímico del asco en el caso presentado da cuenta de un elemento perturbador del duelo. No hay duelo, al menos no en su forma típica. No hay sufrimiento ni dolor por la pérdida, hay en cambio asco. Es posible entonces pensar que el estado afectivo del duelo se vea perturbado por las barreras anímicas (en este caso el asco), por la reaparición de las mismas, modificando en lo sucesivo el proceso. Hay entonces un elemento culposo de fondo que se instala sobre el asco sustituyente del dolor por la pérdida. El duelo, concebido como un estado afectivo, puede verse taponado, bloqueado por los diques anímicos, los cuales son a su vez estados afectivos. Un afecto puede inhibir, frenar, obstaculizar, la apertura de otro proceso afectivo. ¿No vemos de manera destacada la presencia del ansia de venganza, el coraje avasallador, como dique anímico para impedir que se lleve a cabo lo que Freud concebía como trabajo de duelo? Pero puede ocurrir también que la pérdida convoque experiencias donde más que tristeza y aflicción surja la presencia de un cuerpo repugnante, de un cuerpo asqueroso, de un cuerpo que con sus flujos y secreciones resulta indigerible.

Es innegable el componente culposo que este caso delata. El fenómeno de la culpa está anclado, además, a las prácticas de corte a partir de la pérdida del ser-amado. Pero ¿culpa ante qué? Ya Freud (1915/2006) advertía del fenómeno culposo y autopunitivo de la ambivalencia hacia los objetos amados, los que después, perdidos en la realidad, muertos, implican una suerte de "duelo patológico" comandado por el autocastigo que existe en tanto escamoteo del deseo de muerte hacia aquel que ahora está muerto, o que más bien, "ya no está aquí". Lo que delata la autopunición es que hay algo ahí -escrito, dicho sobre la piel- qué castigar. La misma chica expresa: “... iqué gacho que lo mataron pero a la vez qué bueno! Gacho porque pudo dar más". La ambivalencia en este caso es notable. El placer mezclado con el dolor, otorga un sentido gozoso al cuerpo que se duele por la pérdida. ¿No es precisamente el goce el que ancla al sujeto a un (y aún) otro, a un objeto, mucho más allá del dolor, del sufrimiento, de la violencia y a veces de la muerte misma? Esta violencia ejercida sobre el cuerpo propio otorga al goce ciertos tintes perturbadores del duelo. La expresión "qué gacho" tiene en nuestro contexto cultural el sentido de locución e interjección que se emplea "para expresar disgusto ante una actitud egoísta o poco solidaria" (Academia Mexicana de la Lengua, 2010, p. 241). No se sabe a qué o a quién atribuir la molestia ante este egoísmo o falta de solidaridad ¿El disgusto es la posición subjetiva de ella ante este crimen cometido contra alguien que abusó de ella? ¿Ella hubiera preferido participar de ese crimen cometido por unos criminales egoístas? También la palabra "gacho" alude a alguien "ruin, vil" (p. 241). Parece que en este caso el egoísta resulta ser la víctima que parece malvado porque con su muerte se llevó lo que todavía podría dar. Como si todavía tuviera en su poder dones que conceder, dones que se le podrían pedir.

Las cortaduras sobre su cuerpo lo impregnan de erotismo en el proceso de duelo. Sus piernas libidinizadas, 
partes del cuerpo erotizadas y erotizantes delatan un duelo que de otra forma no puede hacerse. Es abrir un agujero, mediante cada rajadura, representante del agujero que la muerte ya produjo, con toda la carga erótica que ello conlleva. El cuerpo, como receptor primero de la pérdida, sufre lo indecible del sufrimiento. El cuerpo porta y soporta un sufrimiento que no puede decirse. Entonces hay que hacer sangrar un cuerpo que no puede llorar su pérdida. El cuerpo duele, el cuerpo se inhibe y se experimenta como vacío, casi como si se tratase de un cuerpo en duelo, si tan solo éste no fuese erotizado por el sujeto, el verdadero sufriente. Encontramos entonces una especie de contraste llamativo. En el amor en línea el gasto represivo se economiza, se ahorra, mientras que en la escarificación nos tropezamos con ese complemento cruento de "sadismo del superyó y el masoquismo del yo" (Freud, 1924/2006, p. 175), donde no se economiza nada, de dolor ni de libido, en el afán autodestructivo.

El dolor del sujeto que se corta va más allá del dolor físico. Corresponde a la unión tanto de dolor físico como de dolor psíquico; dolor objetivo-corporal y dolor subjetivomoral. Ambos elementos adquieren fuerza y se unen cuando el sujeto que se corta rememora en su acto un dolor, que es precisamente un dolor psíquico ahora vuelto físico. Cambio necesario cuando la palabra corre sin hallar sentido en su propio discurso. El no recordar trasmutado en repetición, escribía Freud. Es el recuerdo hecho acto, y el retorno de la muerte, situación que abarca el innegable aspecto del daño al cuerpo, de la fascinación por el desecho de ese corte y el discurso desordenado, todo al mismo tiempo, casi a manera de ejemplo de lo hipermoderno. El placer y el displacer en una dialéctica de goce, ahí es donde se encuentra situado el sujeto que sufre. El dolor que no se dice ni articula, es aquel no traducido simbólicamente. Hay, por supuesto, dolores intraducibles. Incluso el dolor mismo puede arrancarnos de la condición misma de sujetos.

Al cortarse, nuestro sujeto sabe que le duele. Dice que lo que duele es la lesión, prefiriendo así el dolor sobre la carne, un dolor autoprovocado, evitando el dolor psíquico, y apelando a la vieja fórmula de "anular un dolor provocando otro", y anular un dolor que viene desde el otro. En palabras de Freud; "el analizado no recuerda, en general, nada de lo olvidado y reprimido, sino que lo actúa. No lo reproduce como recuerdo, sino como acción; lo repite, sin saber, desde luego, que lo hace" (Freud, 1914/2006, p 152). El duelo puede configurarse desde esa dialéctica del cuerpo que delata una pérdida insoportable, insondable.

La lesión corporal entonces adquiere un valor singular e importante a destacar. No se trata de hacer el corte por el recuerdo doloroso de algo, sino de evitar el dolor venido de otros lados hiriendo al cuerpo propio, muchas veces hasta que éste ya no puede más. La lesión provocada sobre el cuerpo también provee la ventaja de que el sujeto al momento de infligirse la herida, no sólo centra su dolor en la lesión corporal, sino que su representación mental está asimismo sobre la carne cortada, quemada, la sangre que corre o la ampolla de las quemaduras que se va formando. "La sensación dolorosa resulta reavivada por el surgimiento de la representación mental de la herida" (Nasio, 2005, p. 86). Al sentir el dolor sobre el cuerpo, se cree y asume que su impresión procede exclusivamente de la abertura de la piel.

Algo se oculta detrás del dolor físico, o bien, el mismo dolor físico es sustituto de algo más. Tampoco se reconoce que es un dolor que está ahí por la desaparición del otro, ni que ha sido abandonado por el otro. Siendo ahora el sujeto mismo actor y responsable de esos cortes, no se reconoce un duelo como tal, sino que se hace un intento de retorno del dominio de sí. No se reconoce que el corte viene del otro. De su ausencia.

Una mujer marca su cuerpo mediante quemaduras. Cada quemadura conmemora una pérdida, una quemadura por pérdida. Y recuerda cada una de estas pérdidas: el abandono por parte de quien fuera su objeto de amor, su novio de muchos años, la fecha de cada aniversario que ya no siguen cumpliendo, un aborto en la adolescencia, otro aborto más reciente, el nacimiento de su hija (el cual representa la pérdida absoluta de lo que a ella le gustaba hacer y ser), el inicio de un matrimonio infeliz, constituyen sus grandes pérdidas. Cada una de sus pérdidas se encuentra encarnada en ella. Se marca como forma de duelo por sus objetos: el sentirse abandonada reabre al agujero de la falta, hay una quemadura por cada hijo no nacido, pero también hay otra de la hija que sí nació y que significó también una pérdida, la mayor de ellas, la pérdida de la libertad. Relata y delata su deseo:

A veces pienso en matar a los que quiero pero que me estorban, mi esposo y mi hija. Si a mi hija le hago esto ni quién se sepa. Sería una liberación. Pero a la vez soy cobarde porque lo pienso pero Dios no me ha dado la oportunidad. (Soria, 2011, p. 211)

También duele la falta de libertad, también por ella se puede hacer duelo. Freud ya lo advertía desde su definición del duelo como "la reacción frente a la pérdida de una persona amada o de una abstracción que haga sus veces, como la patria, la libertad, un ideal, etc." (1915/2006, p. 241). Y nuevamente, es el cuerpo el receptor de este duelo y este dolor, mediante él se hace un intento de subjetivar las pérdidas. Un duelo que de otra forma no puede hacerse.

En ambos casos hay indicios de un juego con la muerte a partir de las muertes de los otros. Menciona Lacan: "Abordamos, también, la cuestión del objeto desde un ángulo totalmente diferente, cuando hablamos del objeto en tanto que el sujeto se identifica, allí, en el duelo" (1959/2014b, p. 377). Ese juego con la muerte, tan característico de la contemporaneidad, es otro eslabón que 
hace enlace entre cuerpo, pérdida y duelo. Identificación con el objeto perdido, y no del tipo de identificación propia de la melancolía, sino identificación con la condición de muerto. Así, la sensación característica de vacío en el duelo, aunada con las inhibiciones propias de dicho estado, y la falta de interés por el mundo (sentido también como vacío), encuentra una nueva forma de ser explicado, ahora desde la posición del sujeto devuelto a su condición de faltante.

En cierto modo, el duelo también implica una suerte de identificación con la muerte del muerto. Para Lacan, el duelo responde a un movimiento configurado desde que se pierde un objeto. No cualquier objeto, sino el objeto soporte de la castración. Con la muerte de este objeto, la castración retorna al sujeto sufriente: "[...] cuando ésta nos retorna nos vemos como lo que somos, en la medida en que nos vemos esencialmente devueltos a esa posición de castración" (Lacan, 1963, p. 125). ¿Ser devueltos a la posición de castración no es, en cierto modo, también enfrentarnos con la posibilidad de nuestra muerte? Nada nos acerca más a la posición de falta y de muerte, nada nos hace encontrarnos en la posibilidad de finitud de todo, que perder a aquellos que soportan dicha falta. Como en nuestros dos casos: erotismo culposo reavivado por el muerto y corporeidad del abandono, la muerte y la terminación de la libertad.

Si el dolor ocupa sitio de frontera anímica, o, como dice Nasio (2005), "un fenómeno límite" (p. 23), el estado subjetivo de duelo no está muy distante de tal posicionamiento. El duelo de hecho se traspone en vivencias intensas de dolor. De dolor que desborda el cuerpo. O bien de dolor que se llevan al cuerpo, que comprometen el cuerpo. Se conocen bien las coerciones sobre el cuerpo para el cumplimiento del ceremonial de duelo. David prescribiendo el rasgamiento de vestiduras y el ceñimiento de los cilicios para hacer el duelo ante la muerte de Abner. En el Libro de los Macabeos también aparece en el establecimiento de culto de duelo junto al rasgamiento de vestiduras, el acto de echarse ceniza sobre la cabeza. Coerciones del cuerpo pero en un duelo comunitario. Hoy la comunidad está menos implicada. "El modelo de la muerte hoy sigue estando determinado por el sentimiento de privacy, pero vuelto más riguroso, más exigente" (Ariès, 1999, p. 507). Este sentimiento de privacidad se agudiza de tal modo que el duelo se monta de modo estricto sobre el cuerpo. Entonces el duelo se convierte en un asunto donde la familia se encierra en sí misma, se repliega, para realizar sus funerales en privado. Parece que la sociedad en sus sistema de vigilancia y control propugna por "tener vergüenza de la muerte" (p. 508). Este dique anímico contra un eventual exceso de placer o contra el placer como exceso ahora se erige ante la muerte. Pero ante la muerte del otro, hacia el ser amado. La cual "suscitaba un patetismo antiguamente rechazado" (p. 505) y resultando insoportable para un yo que apuntala en la tecnología médica las fortificaciones de la supuesta inmortalidad. Así el luto, el llamado trabajo de duelo, se traslada al cuerpo, mortificándolo. Es lo que propone Anne Dufourmantelle cuando plantea eso que puede ocurrir con el cuerpo ante lo dramático de una ruptura amorosa: "Se debería observar más los minerales, las piedras, la lava petrificada, los fósiles, la roca -nos dicen lo que somos. Es en esta mineralidad en la que uno se parapeta cuando el amor se les retira" (2012, p. 51). El cuerpo se mineraliza, se petrifica, se fosiliza, para resguardarse. Para no arriesgarse más, para no llevar la exposición del dolor al seno de lo virtual y su mediación imaginaria, el cuerpo mismo se hace parapeto.

Parece que el cuerpo no estuviera ni preparado ni hecho para el abandono. Sufre abismalmente esta desesperación, reverso de la pasión dice Galimberti (2011, p. 172). Lo que nos evoca el pasaje de Kierkegaard (2005) donde la experiencia desesperante de tener que ser "un yo sin el otro" (p. 30) señala el "vacío abominable" producido por el abandono del otro, vacío repugnante, vacío impúdico y abyecto. Vacío que muestra la demolición de los diques anímicos: vacío vergonzoso, vacío doloroso, vacío asqueroso: "El desesperado es un enfermo de muerte" (p. 31). Y en el cuerpo se lleva a cabo este proceso doloroso de desinvestidura a la que el mismo yo instado por su cobertura narcisista se resiste. ¿Cómo poner en palabras el dolor de este abandono para el cual no estamos preparados en tanto no venimos al mundo en soledad? Es aquí donde el analista puede escuchar ese dolor decirse o transmitirse a través del cuerpo: "Es el cuerpo entero que se convulsiona, y en la vacuidad de las palabras, unas imágenes repetitivas, unos recuerdos abiertos, una queja anónima se hace escuchar, sin rostro y sin voz" (Dufourmantelle, 2012, p. 52). Hacer en el cuerpo el trabajo de duelo es un ejercicio de apertura y cierre del "dolor de amar al desaparecido" (Nasio, 1999, p. 73). El hecho, dictado por el examen de la realidad, diría Freud, que el ser amado no esté, no hace sino intensificar el amor, de esforzarlo, de abrirlo, en la búsqueda ansiosa, para luego cerrarlo en la decepción de lo inalcanzable. El amor, aunque Freud diga que parece que con él "se podría obtenerlo todo" (1914/2006, p. 171), no es mágico, ni omnipotente. El dolor de amar se vuelca en un amar doloroso, incontenible, pero también en un amar el dolor que parece ceñido, pegado, replegado sobre el ausente. Para inscribir este dolor de amar en correlación con este amor sobre el dolor que une con el ser amado están los tatuajes, las escarificaciones. Marcas de la memoria del dolor de amar que sustentan una historia que no está para contarse sino para cortarse.

Lo que cada escarificación instaura es al cuerpo como memoria, lo que cada escarificación plasma son, diría Lacan (lección del 30 mayo de 1962) "efectos encarnados de ese hecho de la primacía del significante sobre el sujeto". Sin pudor el sujeto muestra las marcas de su historia en el cuerpo. En el cuerpo aparece hasta de manera ostentosa la 
relación circunstancial del acontecimiento. Lo que se relata exhibiendo las llagas, las huellas, que diferenciadas, hacen acopio de una violencia, de un poder presunto, sobre el cuerpo. Alarde de dominio que hace sintonía con ejercicio de impudicia: "El impudor ha devenido virtud. No tener nada que esconder, no tener vergüenza de nada, y estar listo, el dedo sobre la costura del pantalón, para entrevistas, confesiones públicas, revelaciones sobre su intimidad" (Galimberti, 2011, p. 133). Las heridas no se oculta se revelan en los "reality shows". Exponer públicamente el dolor es espectáculo donde la vida íntima deviene "una propiedad común" (p. 133). Si el cine de ciencia ficción fascina con los cuerpos de los muertos vivientes, con los cuerpos sin sepultura, "como signo de la perturbación del rito simbólico" (Zizek, 2004, p. 48), con la abyección de los flujos y secreciones saltando a borbotones, la televisión se solaza con las almas que se desgarran exhibiendo sus intimidades. Cuerpos que soportan el duelo-no hecho en su muerte viviente y almas que exhiben sus miserias para un solaz esparcimiento del goce. Es la comunidad extensa de la impudicia. La cual se ha labrado un ejercicio de poder gestado desde la imaginación orwelliana hasta las prácticas más abyectas de espionaje. La videovigilancia ha sofisticado la intrusión portentosa a nivel mundial bajo la premisa radical de la seguridad. Lo que se ha globalizado no es sólo el acceso al conocimiento ramificado y jerarquizado sino también las tecnologías del panóptico. Es lo que expone el investigador de la Universidad Autónoma del Estado de México, Nelson Arteaga al señalar que:

[...] más que la distopía de George Orwell en 1984, nos acercamos al Neuromancer del escritor William Gibson, quien describió una sociedad en donde todos vigilan a todos y por eso se anhela tener privacidad. Más que un Gran Hermano, vivimos con muchos pequeños hermanos que capturan nuestra información sin que nos demos cuenta a través de Facebook y Twitter. (Camacho, 2013, p. 41)

Todos sin el menor pudor nos podemos meter con todos. Es la apuesta perversa del caos, indicada por Galimberti (2011). Apuesta que involucra también está practica cada vez más socorrida de video-grabar la falta del otro, de captar infraganti al partido o contrincante político, cometiendo algún desliz o diciendo discursos que pueden calificarse muchos de ellos como cínicos. Una especie de cultura paranoica nos circunda cifrada en la impresión de que en cualquier momento podríamos ser víctimas del otro, quien podría estarnos filmando sin nuestro permiso y podría subir nuestra imagen, también sin nuestra autorización, a la red intergaláctica. La obsesión por visibilizar todo lleva a la cúspide el emblema atroz de una modernidad en el sentido de que nada es imposible. Particularmente para los ojos y los odios de quienes ejercen el poder.

\section{Conclusión}

La Aubhebung en Freud permite concebir la relación paradójica en la cual se inscriben los poderes resistenciales al placer en el sujeto. Lo detienen, lo contienen, lo limitan, pero cuando se ven superados lo exacerban. En esa superación radica su conservación y mantenimiento. Esos poderes afectivos de los diques anímicos son un aliciente para todo atrevimiento. Son puestos a prueba en su condición de razón última el pudor y el dolor. El amor en línea levanta la barrera de la vergüenza para hacer alarde de audacia ante lo que le demande el otro al sujeto en sus deslices impúdicos. Pero la pantalla del monitor resguarda de la conexión e interpenetración de los cuerpos. La osadía del radicalismo individual de la era digital encuentra su correlato en la que se toman los jóvenes al experimentar con el dolor producido violentamente en sus cuerpos. No ocupan de otro para agudizar la sensación de vitalidad mediante el dolor. El cual es paralelamente límite al placer e incentivación al mismo. Pero los diques anímicos pueden establecer una relación dialéctica entre ellos. Superarse unos en relación con otros $\mathrm{y}$, en ese sentido, mantenerse en referencia a otros. El asco puede doblegar el dolor del duelo ante una experiencia de perdida. El amor en línea hace de un estado afectivo íntimo una expansión de pasión disponible para todas las miradas. El duelo, en cambio, se restringe, se acota, se hace un asunto tan privado, tan individualista, que se consume y consuma en el cuerpo.

\section{Referencias}

Academia Mexicana de la Lengua. (2010). Diccionario de mexicanismos. México: Siglo XXI.

Ariès, P. (1999). El hombre ante la muerte. Buenos Aires: Taurus.

Buchanan, C. (Productor), \& Whedon, J. (Director). (2005). Serenity [Película]. Estados Unidos: Universal Pictures.

Camacho, F. (2013). Vigilar a través de cámaras, tendencia global de control y exclusión social. La Jornada, 41 .

Coetzee, J. M. (2003). En medio de ninguna parte. México: Mondadori.

Courtine, J.-J. (2006). Introduction. Histoire du corps 3. Les mutations du regard. Paris: Seuil.

Dejours, C. (1992). Investigaciones psicoanalíticas sobre el cuerpo. Supresión y subversión en psicosomática. México: Siglo XXI. 
Dor, J. (1996). Clínica psicoanalítica. Barcelona: Gedisa.

Dufourmantelle,A.(2012). Encas d'amour. Psychopatologie de la vie amoureuse. Paris: Payot \& Rivages.

Freud, S. (1905/1999). Drei Abhandlungen zur Sexualtheorie. In Gesemmelte Werke, $V$. Frankfurt am Main: Fischer.

Freud, S. (1905/2006a). Tres ensayos de teoría sexual. In Obras Completas (Vol. VII). Buenos Aires: Amorrortu.

Freud, S. (1905/2006b). El chiste y su relación con el inconsciente. In Obras Completas (Vol. VIII). Buenos Aires: Amorrortu.

Freud, S. (1908/2006). Las fantasías histéricas y su relación con la bisexualidad. In Obras Completas (Vol. IX). Buenos Aires: Amorrortu.

Freud, S. (1914/2006). Recordar, repetir y reelaborar. In Obras Completas (Vol. XII). Buenos Aires: Amorrortu.

Freud, S. (1915/2006). Duelo y Melancolía. In Obras Completas (Vol. XIV). Buenos Aires: Amorrortu.

Freud, S. (1924/2006). El problema económico del masoquismo. In Obras Completas (Vol. XIX). Buenos Aires: Amorrortu.

Freud, S. (1929-30/2006). El malestar en la cultura. In Obras Completas (Vol. XXI). Buenos Aires: Amorrortu.

Galimberti, U. (2011). Qu'est-ce que l'amour? Paris: Payot.

Goldsman, A. (Productor), \& Lawrence, F. (Director). (2007). I Am legend [Película]. Nueva York: Warner Bros.

Hegel, G. W. F. (1982). Fenomenología del espiritu. México: Fondo de Cultura Económica

Kierkegaard. (2005). Tratado de la Desesperación. Buenos Aires: Leviatan.

Kleiner, J. (Productor), \& Forster, M. (Director). (2013). Guerra Mundial Z [Película]. Reino Unido: Paramount.

Kristeva, J. (2006). Poderes de la Perversión. México: SXXI.

Lacan, J. (1958-9). Falofahía. Clase 19, 29 de abril de 1959. In Seminario 6. El deseo y su interpretación [Versión electrónica].
Lacan, J. (1958-9). El deseo de la madre. Clase del 18 de marzo de 1959. In Seminario 6. El deseo y su interpretación [Versión electrónica]

Lacan, J. (1962). Lección del 30 de mayo. In Seminario 9. La identificación [Inédito, Versión electrónica].

Lacan, J. (1962-3/2009). Del Cosmos al Unheimlichkeit Clase 3, 28 de noviembre de 1962. In Seminario 10. La Angustia. Buenos Aires: Paidós.

Lacan, J. (1965). Leçon du 3 février 1965. In Le Séminaire 12. Les problems cruciaux pour la psychanalyse [Inédito, Versión electrónica].

Lipovetsky, G. (2006). Los tiempos hipermodernos. Barcelona: Editorial Anagrama.

Lyotard, J. F. (1991). La condición posmoderna. Informe sobre el saber. Madrid: Ed. Cátedra.

Nasio, J. D. (1999). El libro del dolor y del amor. Barcelona: Gedisa.

Nasio, J. D. (2005). El libro del dolor y del amor. Barcelona: Gedisa.

Nasio, J. D. (2006). Los gritos del cuerpo. Psicosomática. Buenos Aires: Paidós.

Picard, D. (1986). Del código al deseo. El cuerpo en la relación social. Buenos Aires: Paidós.

Soria, H (2011). Marcas en el presente, huellas del pasado. Un estudio psicoanalítico en torno al maltrato corporal. Tesis de maestría inédita, Universidad Autónoma de Querétaro, México.

Vattimo, G. (1987). Introducción al "Ser y Tiempo" de Heidegger. México: FCE.

Zizek, S. (2004). Mirando al sesgo. Una introducción a Jacques Lacan a través de la cultura popular. Buenos Aires: Paidós. 
Endereço para correspondência:

Mario Orozco Guzmán

Endereço: Calle Coronel Amado Camacho, $\mathrm{n}^{\circ}$ 570, Col. Chapultepec Oriente, Morelia. Michoacán/Mexico, CP:

58260.

E-mail: orguzmo@yahoo.com.mx

Endereço para correspondência:

Hada Soria Escalante

Endereço: Calle Coronel Amado Camacho, $\mathrm{n}^{\circ}$ 570, Col.

Chapultepec Oriente, Morelia. Michoacán/Mexico, CP:

58260.

E-mail: hadasoria@hotmail.com 